\title{
The Roles of Relationships and Service Quality as Drivers of Customer Loyalty: An Empirical Study
}

\author{
Osman Mohamed Ali \\ School of Business Administration, South China University of Technology, Guangzhou, China \\ Email: jundintod@gmail.com
}

How to cite this paper: Ali, O. M. (2020). The Roles of Relationships and Service Quality as Drivers of Customer Loyalty: An Empirical Study. Open Journal of Social Sciences, 8, 14-32.

https://doi.org/10.4236/jss.2020.84002

Received: September 21, 2019

Accepted: March 29, 2020

Published: April 2, 2020

Copyright ( 2020 by author(s) and Scientific Research Publishing Inc. This work is licensed under the Creative Commons Attribution International License (CC BY 4.0).

http://creativecommons.org/licenses/by/4.0/

\section{(c) (i) Open Access}

\begin{abstract}
This study empirically examines 270 B2B firms based in Guangdong province, China, in an attempt to increase understanding of the interplays between service quality, relationship quality and customer loyalty from a social exchange theory viewpoint. The study reveals that service quality is positively related to relationship quality, relationship quality is positively related to customer loyalty, and service quality is positively related to customer loyalty. At the same time, relationship quality partially mediates the relationship between service quality and customer loyalty. The study offers useful insights to practitioners on how to cultivate better relationships with collaborators through offering better services which in turn help them retain customers.
\end{abstract}

\section{Keywords}

Service Quality, Relationship Quality, Customer Loyalty, Social Exchange Theory, Business-to-Business

\section{Introduction}

In an increasingly competitive environment, all businesses must be customer-oriented (Kotler, 1997) and focus on delivering high quality services in order to survive and prosper in today's competitive marketplace (Meesala \& Paul, 2018; Zeithaml et al., 1996). In recent years, the concept of customer loyalty is getting more and more attention (Moretta et al., 2019). Whether in academia or industry customer loyalty is widely regarded as the basis of business success. Higher customer loyalty helps reduce marketing expenses, accelerate the process of brand building, reduce the cost to retain customers, and bring new customers through recommendations of old ones, as well as bestowing the firm with a bet- 
ter resistance in the face of competitive strategies of competitors and ultimately increasing profits (Caceres \& Paparoidamis, 2007). Therefore, loyal customers are vital for the survival and development of firms. Providing high-quality service is a key strategy for success in today's highly competitive environment ( $\mathrm{Pa}$ rasuraman et al., 1985a), this is why the important element of service quality has been attributed with a great concern in the traditional marketing paradigm as well. With diminishing products differentiations, and the increasing importance of interactions between firms and customers during the processes of product and service development and delivery, relationships are attaining increasingly prominent positions as a result, to some extent, relationships importance can even surpass the quality of products and services themselves. This laid the basis for the generation and growing interest in relationship marketing paradigm.

According to social exchange theory, due to the existence of an invisible and unspecified form of mutual responsibility, when one party benefits from another one, the other party will feel responsible to return the favor at a future time, this exchange can take many different forms (Blau, 2017), after the establishment of interaction between firms and customers, the above mentioned favor exchanges will lead to customer loyalty. Grönroos (2002) pointed out that business-customer relationship establishment can be divided into two types: the first is to attract customers, the second is to establish a relationship with customers in order to achieve some economic goals out of the relationship.

The cost of attracting new customers is much higher than the cost of retaining old customers (Liu et al., 2011), and therefore answering to the diverse needs of customers and gaining their loyalty are important goals for today's managers, they can achieve these goals through developing long-term, mutually beneficial relationships with customers (Athanasopoulou, 2009), the importance of customer loyalty is self-evident.

Reviewing the extant literature, we noted that service quality and relationship quality are some of the hottest research topics in recent years, many scholars have investigated the relationship between service quality and customer loyalty, a great deal of research also examined the interactions between customer satisfaction, trust, and loyalty (Singh \& Sirdeshmukh, 2000; Carrillat et al., 2009; Nguyen et al., 2013), however, few researchers explored the relations between overall relationship quality (including its three dimensions: satisfaction, trust and commitment) and customer loyalty from the perspective of relationship marketing. Moreover, the literature demonstrates interesting advancements in the understanding and conceptualization of customer loyalty. However, up to now, further research efforts are urgently required in this area of study (Moretta et al., 2019; Nguyen et al., 2018; Iqbal et al., 2018; Sitorus \& Yustisia, 2018). In addition, contemporary management practices in the manufacturing industry in China continue to focus on products and prices, while some scholars have repeatedly called for enhancing the quality of services to improve the relationship quality and customer loyalty in the service industry. Therefore, this study takes 
eyewear processing and manufacturing industry in Guangdong province as an example to investigate the relationships between service quality, relationship quality, and customer loyalty, aiming at clarifying the mechanisms by which service quality influences relationship quality and customer loyalty in the processing and manufacturing industry, compensating for the lack of relevant research works, and providing some guidance for firms regarding how to reduce costs and enhance competitiveness.

This study is relevant from the viewpoints of both theory and practice. From a theoretical viewpoint, the findings of this research contribute to a better understanding of the antecedents of customer loyalty. From a managerial viewpoint, we offer guidance for service providing firms regarding the suitability of the strategies they employ to cultivate customer loyalty.

\section{Literature Review}

Services are intangible and perishable, these characteristics will render customers to have feelings of uncertainty or unease, these undesirable feelings usually mean invalid service or negative results (Crosby et al., 1990), while providing services with good quality will put customers at ease and eliminate their worries by reducing uncertainty, which will eventually lead to enhancing relationship quality between the two sides. From the customer's viewpoint, relationship quality is attained through capable sales staff who make customers' feelings of uncertainty go away. From a business-to-business viewpoint, the supplier's ability to reduce customers' feeling of uncertainty will affect the quality of the relationship.

Service quality is a multidimensional concept that continues to evolve. Service quality presents a highly important problem that contemporary management needs tp solve (Cronin \& Taylor, 1992). Through delivering superior levels of service quality, service providers can favorably position themselves in the market. However, one significant issue is that service quality is an elusive and abstract concept that is not easy to define and measure (Parasuraman et al., 1985). Customers' loyalty to service firms relies more on interpersonal relationships development as contrasted to customers' loyalty to firms producing tangible products, since the perceived risk is greater in services offerings than products. Service quality relies on two variables: expected service and perceived service, additionally, customers are not only interested in what service they get as a result of the production process, but in the process itself (Grönroos, 1984).

Typically, service demands high customer involvement in the consuming process. In the interactions between seller and buyer, while simultaneously producing and consuming of a service, customers are active participants that evaluate the whole process (Grönroos, 1984). Service quality is an antecedents of customer satisfaction (Cronin \& Taylor, 1992) that can lead to better relationships between a firm and its customers. This study defines service quality a form of attitude, connected to but not equivalent to satisfaction, which is the outcome 
of comparing expectations and performance (Cronin \& Taylor, 1992).

The literature implies that customer loyalty can be defined in two different ways. The first one defines loyalty as an attitude. Different feelings create an individual's overall attachment to a product, service, or organization. These feelings define the individual's degree of loyalty. The second definition of loyalty is behavioural. Instances of loyalty behaviour encompass continuing to purchase services from the same supplier, increasing the scale and or scope of a relationship, or recommending (Hallowell, 1996).

Kalepu (2014) found that demographic factors and socioeconomic status had a deep effect on customers' satisfaction. Hallowell (1996) found support for the theory that customer satisfaction is connected to customer loyalty, which consequently is connected with profitability.

Merkert and Pearson (2015) examined the effect of customer service satisfaction on the financial performance of airline firms. They also investigated potential strategies for enhancing service performance and profitability.

Hussain et al. (2015) examined the correlations between service quality, customer perceived value, customer expectations and satisfaction, and loyalty. They employed SERVQUAL framework to identify the influencing factors of service quality of an airline company located in Dubai. They consequently utilized service quality as a driver of customer satisfaction. They used reliability, responsiveness, safety, tangibility, communication, and assurance as the dimensions of service quality.

Loyalty is a feature of people, rather than something inherent in firms (Uncles et al., 2003). Hence, the importance of relationships between firms and customers to foster customer loyalty, which will in turn lead to enhanced relationships. Numerous previous research has been allocated to examining the antecedents and consequences of customer loyalty (Pan et al., 2012) because loyalty is connected with other complex constructs such as customer involvement, trust, satisfaction, commitment, and engagement (Hajli et al., 2017), that's to say, related to relationship quality. This study defined relationship quality as the degree to which both parties in a relationship are engaged in an active, long-term working relationship and operationalised the construct using indicators of satisfaction, trust, and commitment (Hewett et al., 2002).

Shi et al. (2018) investigated the impact of online service quality on swift guanxi that influences customer repurchase intention and the moderating role of gender in the relationship between online service quality and swift guanxi. Walsh et al. (2008) offered insights into the relationship between customer satisfaction and customer loyalty by examining the effects of particular moderators.

Considering the opinion and feedback of travelers helped providing better service in the competitive airline industry (Beneke, Mill, Naidoo, \& Wickham, 2015; Lee, Lee, Chuang, \& Wu, 2014; Lerrthaitrakul \& Panjakajornsak, 2014; Punel et al., 2019). 


\section{Theory and Hypotheses}

\subsection{Social Exchange Theory and Customer Loyalty}

Social exchange theory (SET) is one the most influential conceptual paradigms in organizational behavior (Cropanzano and Mitchell, 2005). Scholars agree that social exchange requires a series of interactions that create obligations. Within Social Exchange Theory, these interactions are usually perceived as interdependent and contingent on the actions of other people (Blau, 2017), these interdependent transactions are expected to create high-quality relationships which will lead to loyal customers.

\subsection{Hypotheses Development}

Crosby et al. (1990) proposed a relationship quality pattern arguing that professional services provided by services staff have a positive impact on relationship quality, and further proposed that service quality is an important condition of relationship quality. Caruana (2002) found that higher service quality provided by a corporate is related to higher customer satisfaction and reliability, accordingly proposing that service quality and relationship quality are significantly correlated. When studying the antecedents of relationship quality, some scholars found that the quality of service simultaneously impacts customer satisfaction and trust (Liu et al., 2011). Service quality plays a vital role during the process of building long-term relationships between businesses and customers (Carrillat et al., 2009). Therefore, this paper proposes the following assumption:

H1: Service quality has a positive impact on relationship quality.

Service quality is all about customers and customers' awareness of the quality of service would have a significant impact on their behavior. Investigating service quality, Parasuraman et al. (1991) argued that customer perception of service quality will positively impact their willingness to recommend the firm to others, and willingness to recommend is an important indicator of customer loyalty. Therefore, the quality of service will have a direct impact on behavioral intentions of customers, including the behavior of customers recommending the service to others (Chenet et al., 2010). Through improving service quality of a firm, not only customers needs will be met and their willingness to buy will be enhanced, but also will lead to customers willingly recommending the services to other people, which is a manifestation of customer loyalty. Hazra and Srivastava (2009) tracked down and interviewed 300 corporate customers, their results showed that by providing higher quality services, firms won customers' loyalty. Therefore, we propose the following hypotheses:

H2: Service quality has a positive impact on customer loyalty.

The relationship between customer satisfaction and customer loyalty has been covered in a great deal of previous research works, related literature showed that there is a positive link between customers' behavioral intentions and customer satisfaction (Caceres \& Paparoidamis, 2007). Similarly, Anderson and Sullivan (1993) found that there is a strong correlation between intention of declaration 
repurchase and declaration satisfaction. Because customer satisfaction, Since customer loyalty represents behavioral intention of a satisfied customer to maintain relationships with the current service providers, therefore, customer evaluation of service provider's trustworthiness will positively affect the degree of relationship loyalty with the service provider (Singh \& Sirdeshmukh, 2000). In addition, customers repurchase behavior will be influenced by the extent of their commitment to buy the specified brand, which suggests that repurchase behavior alone does not mean customers are loyal, truly loyal customers will repurchase their specified brands due to commitment, and not just merely because they are used to that brand. Because customers with habitual repurchasing behaviors are likely to switch brands as soon as a competitor cuts prices or offers some coupons (Caceres \& Paparoidamis, 2007). This indicates that relationship commitment and customer loyalty are positively related, in other words, the higher the relationship commitment, the higher the customer loyalty (Ou et al., 2011). Therefore, relationship quality is one of the key drivers of customers' intention to recommend to other customers (Huntley, 2006). Accordingly, this paper proposes the following hypotheses:

H3: Relationship quality has a positive impact on the degree of customer loyalty.

Effectiveness of services delivered by a business is a key reason for customers to switch suppliers, if a firm is capable of providing high quality services, customer loyalty will be improved, good relationships will be maintained, and customers will be more willing to continue cooperating (Keaveney, 1995). However, the impact of the quality of services on purchase intention is indirect (Carrillat et al., 2009). Quality of services occurs before customer satisfaction, and ultimately leads to the occurrence of overall customer satisfaction; in turn, a satisfactory experience will eventually lead to the realization of customer loyalty (Caruana, 2002). Therefore, the quality of service perceived by the customer influences the degree of loyalty through the overall satisfaction with the service providers (Juga et al., 2010). Trust and commitment are important factors to ensure long-term relationship-orientation, while high relationship quality is a prerequisite for establishing customer loyalty. To secure mutually beneficial relationships with customers, businesses must provide resources (products or services) that are superior to their competitors (Caceres \& Paparoidamis, 2007), which means providing high-quality services and creating superior customer value enables firms to achieve higher customer satisfaction, thus improving the corporate image ( $\mathrm{Hu}$ et al., 2009), thereby winning customers' trust and commitment, and ultimately helping organizations attaining loyal customers. Therefore, we hypothesize the following:

H4: Relationship quality mediates the relationship between service quality and customer loyalty.

Based on the above literature review and development of hypotheses, the conceptual framework of this study is constructed and shown in Figure 1. 
$\mathrm{H} 2$

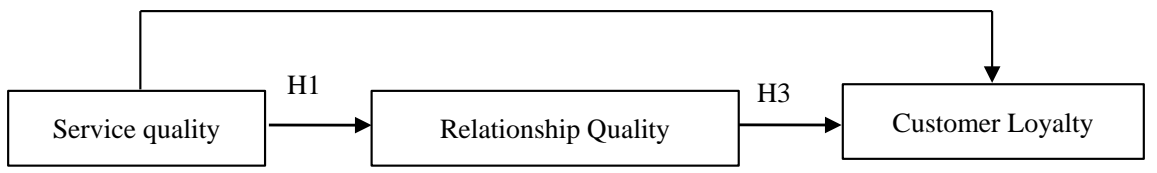

$\mathrm{H} 4$

Figure 1. The conceptual model of this study.

\section{Methodology}

\subsection{Sample and Procedures}

The data in this study is collected from 75 eyewear brands firms and trading organizations in Guangdong Province, We handed out 3 - 4 questionnaires to each firm to investigate their evaluation of their major suppliers. These firms were contacted through Emails, we sent and received the filled questionnaire copies through email. To minimize common method bias, we have conducted two rounds of surveys, with the second round taking place six months after the first one. We started by targeting CEOs and VPs in charge of procurement. We asked CEOs to fill out questionnaires concerning their organizations basic information (age, size, etc.) and their assessment of the relationship quality with the suppliers. While procurement directors were mainly responsible for assessing the quality of services provided by suppliers; Six months later, CEOs and technical directors were asked to assess customer loyalty and service quality of suppliers respectively. In the first round of the survey, we distributed 270 questionnaires, 259 complete copies were returned (including 259 completed CEO questionnaires and 259 completed procurement directors questionnaires). In the second round of surveys, we exclusively targeted those 259 organizations which returned completed questionnaires in the first round. A total of 238 completed copies filled by CEOs and 238 completed copies filled by technical directors were recovered. After matching the questionnaires, the final sample for this study was 202 organizations (including 202 complete CEO questionnaires, 202 complete procurement directors questionnaires, and 202 complete technical directors questionnaires).

The structure of the sample firms as shown in Table 1, revealed the following: firm age: less than 5 years accounted for $12 \%$; 6 - 10 years accounted for $57.3 \%$; 11 - 20 years accounted for 21.3\%; 20 years and over accounted for 9.4\%. Capital: 50 million Yuan or less accounted for 46.7\%; 50 million to 100 million accounted for 24\%; 100 million to 1 billion accounted for $22.7 \%$; 1 billion and more accounted for $6.6 \%$. Number of employees: less than 200 employees accounted for 12\%; 201 - 1000 employees accounted for 53.3\%; 1000 employees and more accounted for $34.7 \%$. Male employees accounted for $61.3 \%$ of the respondents. Employees education: master's degree or above accounted for 15.3\%; college or undergraduate education accounted for 81.7\%; high school or college diploma and below accounted for $3 \%$. Generally speaking, the sample is well distributed and representative. 
Table 1. Demographics of the sample.

\begin{tabular}{|c|c|c|}
\hline \multicolumn{2}{|c|}{ Variables } & \multirow{2}{*}{$\begin{array}{c}\text { Percentage (\%) } \\
61.3\end{array}$} \\
\hline \multirow{2}{*}{ Gender } & Male & \\
\hline & Female & 38.7 \\
\hline \multirow{3}{*}{ Education } & Diploma & 3 \\
\hline & Bachelor Degree & 81.7 \\
\hline & Masters Degree and above & 15.3 \\
\hline \multirow{4}{*}{ Annual Sales } & 50 millions and less & 46.7 \\
\hline & 50 million - 100 million & 24 \\
\hline & 100 million - 1 billion & 22.7 \\
\hline & More than 1 billion & 6.6 \\
\hline \multirow{4}{*}{ Firm Age } & 5 years and less & 12 \\
\hline & $6-10$ years & 57.3 \\
\hline & $11-20$ years & 21.3 \\
\hline & More than 20 years & 9.4 \\
\hline \multirow{3}{*}{ Firm Size } & 200 people and less & 12 \\
\hline & 201 - 1000 people & 53.3 \\
\hline & More than 1000 years & 34.7 \\
\hline
\end{tabular}

\subsection{Measures}

In this study, we adopted tried and tested scales that have been widely used in the published literature in order to ensure the validity and reliability of measurement tools. We conducted exhaustive literature review to find the most mature and most widely used measuring scales, so as to make sure the questionnaire used in this study is designed properly. Some appropriate modifications were carried out as well. Regarding the operational definitions and measuring methods of service quality, relationship quality, and customer loyalty concepts, we adopted ideas from published papers. Before giving out the questionnaires, a pilot test was conducted to evaluate the validity and appropriateness of questionnaire design, revisions were then done based on the feedback received.

Service quality: We used SERVQUAL measure developed by Parasuraman et al. (1985b), regarding tangibility, responsiveness, empathy, reliability, and assurance as dimensions to measure the quality of services. A questionnaire containing 23 questions was developed using the above mentioned measure after slightly modifying it according to the characteristics of eyewear manufacturing and processing industry in Guangdong province. These items were assessed on a five-point Likert scale ( 1 = strongly disagree, $5=$ strongly agree).

Relationship quality: The questionnaire developed by Hewett et al. (2002) was used as a basis with some slight modifications. Satisfaction, trust and commitment were used as indicators of relationship quality, a total of 10 questions consisted this part. Items measuring relationship quality were assessed on 
a five-point Likert scale ( $1=$ strongly disagree, $5=$ strongly agree $)$.

Customer loyalty: Modified version of a questionnaire based on the work of Fornell (1992) was developed. Repurchase, Cross-buying, and Price Tolerance were used as measures of customer loyalty, a total of 3 questions made up this part. Customer loyalty items were evaluated on a five-point Likert scale $(1=$ strongly disagree, 5 = strongly agree).

\subsection{Measurement Assessment}

In this study, the $\mathrm{r}$ values of service quality, relationship quality, and customer loyalty were $0.815,0.827$ and 0.820 respectively. Cronbach's $\alpha$ of all scales exceeded the cut-off of 0.70 . It's noted that all the scales have good reliability. Conducting exploratory factor analysis (EFA) to examine the content validity and construct validity of measurement tools, 5, 3, 1 factors were extracted from service quality, relationship quality, and customer loyalty constructs respectively. With a cumulative explained variance up to $63.806 \%, 60.804 \%$ and $67.687 \%$ for each construct. Varimax method was used to classify items with factor loadings greater than 0.5 into one group. Using this type of rotation, the results agree with the theoretical part. Correlations of items were found to be similar to previous studies. Regarding the risk of common method bias, we used inverted items for some measures and eliminated participants whose responses had the same trend for both inverted and non-inverted items. Moreover, we used the single factor test suggested by Podsakoff et al. (2003), and the results imply that common method variance is not a critical issue in this study. Therefore, we are confident that the measurement scale is reliable and had excellent validity.

\section{Data Analysis}

In this study, SPSS 19.0 and AMOS 20.0 softwares were used to analyze the data collected via survey questionnaires. We conducted factor analysis, validity and reliability tests, model fitness, as well as hypotheses testing, the details of the results of these investigations are displayed in the following sections.

\subsection{Correlation Analysis}

Table 2 summarizes the mean, variance, and correlation coefficient variables. From the table we can see that the quality of service responsiveness $(\beta=0.610, P$ $<0.01)$, reliability $(\beta=0.648, P<0.01)$, and assurance $(\beta=0.593, P<0.01)$ are positively correlated with customer loyalty. Meanwhile, relationship quality satisfaction $(\beta=0.608, P<0.01)$, trust $(\beta=0.742, P<0.01)$, and commitment $(\beta=$ $0.708, P<0.01)$ are also positively correlated with customer loyalty. In addition, service quality and relationship quality are also showing a positive relationship.

\subsection{Model Fit and Hypotheses Testing}

The direct effect test: AMOS19.0 software was used to establish 3 structural models containing 2 latent variables. In Model 1, service quality was the independent 
Table 2. Descriptive statistics and correlation matrix.

\begin{tabular}{|c|c|c|c|c|c|c|c|c|c|}
\hline & 1 & 2 & 3 & 4 & 5 & 6 & 7 & 8 & 9 \\
\hline \multicolumn{10}{|l|}{ 1. Tangibility } \\
\hline 2. Responsiveness & $0.727^{* *}$ & & & & & & & & \\
\hline 3. Empathy & $0.564^{\star \star}$ & $0.557^{\star *}$ & & & & & & & \\
\hline 4. Reliability & $0.545^{* *}$ & $0.598^{* *}$ & $0.698^{\star *}$ & & & & & & \\
\hline 5. Assurance & $0.556^{* *}$ & $0.596^{* *}$ & $0.627^{\star *}$ & $0.661^{\star *}$ & & & & & \\
\hline 6. Satisfaction & 0.174 & 0.216 & 0.311 & $0.529^{* *}$ & $0.628^{* *}$ & & & & \\
\hline 7. Trust & 0.396 & 0.361 & 0.287 & $0.551^{\star *}$ & $0.583^{* *}$ & $0.736^{* *}$ & & & \\
\hline 8. Commitment & 0.367 & 0.296 & 0.131 & $0.636^{\star *}$ & $0.533^{\star \star}$ & $0.595^{\star *}$ & $0.709^{\star *}$ & & \\
\hline 9. Customer Loyalty & 0.194 & $0.610^{* \star}$ & 0.232 & $0.648^{\star *}$ & $0.593^{* *}$ & $0.608^{\star *}$ & $0.742^{\star *}$ & $0.708^{* *}$ & \\
\hline Mean & 3.6460 & 3.5818 & 3.3688 & 3.3085 & 3.3086 & 3.2576 & 3.3095 & 3.3465 & 3.4338 \\
\hline Standard Deviation & 0.7321 & 0.6278 & 0.7598 & 0.6427 & 0.6482 & 0.6000 & 0.6327 & 0.6519 & 0.6797 \\
\hline
\end{tabular}

variable, relationship quality was the dependent variable; In Model 2, service quality was the independent variable, customer loyalty was the dependent variable; In Model 3, relationship quality was the independent variable, customer loyalty was the dependent variable. After computing, factor loading of each latent variable was a standard range of 0.5 to 0.95 , and the factors' loading reached a significant level, with residuals less than 0.6. The main fitness indices of the three models are shown in Table 3, As can be seen from the table, $\chi^{2} / \mathrm{df}$ is less than 5 , CFI is greater than 0.90, RMSEA less than 0.08, AIC and EC are all within the acceptable range, indicating that all the models have high goodness of fit.

Table 4 lists the three validation processes variables' path coefficient estimates. From Table 4 we can see that estimated parameters of each model has passed the test; Fully standardized effect values were $0.611(P<0.001), 0.569(P$ $<0.001)$ and $0.562(P<0.001)$, and they passed the significance test, illustrating that there was a significant positive correlation between service quality and relationship quality, service quality and customer loyalty, and relationship quality and customer loyalty, therefore hypothesis $\mathrm{H} 1, \mathrm{H} 2$, and $\mathrm{H} 3$ are all supported.

Testing of mediating role: We have established a comprehensive analysis model including the three latent variables (service quality, relationship quality and customer loyalty) as shown in Figure 2. In our model, service quality was the independent variable, relationship quality was the mediating variable, and customer loyalty was the dependent variable. Through calculations, all the factor loadings of the impact paths are less than 0.95 . The main fitness indices of the model were: $\chi^{2} / \mathrm{df}=2.498, \mathrm{CFI}=0.982, \mathrm{RMSEA}=0.039, \mathrm{AIC}=126.430, \mathrm{ECVI}=$ 0.532 , indicating a relatively high degree of model fit.

Table 5 lists the path coefficient estimates of the comprehensive model variables. Results in Table 5 shows that all variables estimated parameters have passed the test. Standardized estimates were $0.582(P<0.001), 0.469(P<0.01)$ and $0.624(P<0.01)$, all of which have passed the significance test. Based on that, 
Table 3. Goodness of fit indices of the models.

\begin{tabular}{cccccc}
\hline Model & $\chi^{2} / d f$ & CFI & RMSEA & AIC & ECVI \\
\hline Model 1 & 2.316 & 0.962 & 0.079 & 59.495 & 0.212 \\
Model 2 & 2.130 & 0.932 & 0.075 & 109.751 & 0.414 \\
Model 3 & 2.498 & 0.982 & 0.039 & 126.430 & 0.532
\end{tabular}

Table 4. Path coefficients.

\begin{tabular}{ccccc}
\hline Path & $\begin{array}{c}\text { Standardized } \\
\text { Coefficients }\end{array}$ & S.E. & C.R. & $P$ \\
\hline Service Quality $\rightarrow$ Relationship Quality & 0.611 & 0.163 & 5.352 & $* * *$ \\
Service Quality $\rightarrow$ Customer Loyalty & 0.569 & 0.153 & 5.572 & $* * *$ \\
Relationship Quality $\rightarrow$ Customer Loyalty & 0.562 & 0.104 & 8.818 & $* * *$
\end{tabular}

Note: ${ }^{* *} p<0.001$.

Table 5. Path coefficients of the mediating effect.

\begin{tabular}{ccccc}
\hline Path & $\begin{array}{c}\text { Standardized } \\
\text { Coefficients }\end{array}$ & S.E. & C.R. & $P$ \\
\hline Service Quality $\rightarrow$ Relationship Quality & 0.582 & 0.172 & 6.506 & $* * *$ \\
Service Quality $\rightarrow$ Customer Loyalty & 0.469 & 0.453 & 1.466 & 0.006 \\
Relationship Quality $\rightarrow$ Customer Loyalty & 0.624 & 0.443 & 1.561 & 0.008 \\
\hline
\end{tabular}

Note: ${ }^{* * *} p<0.001$.

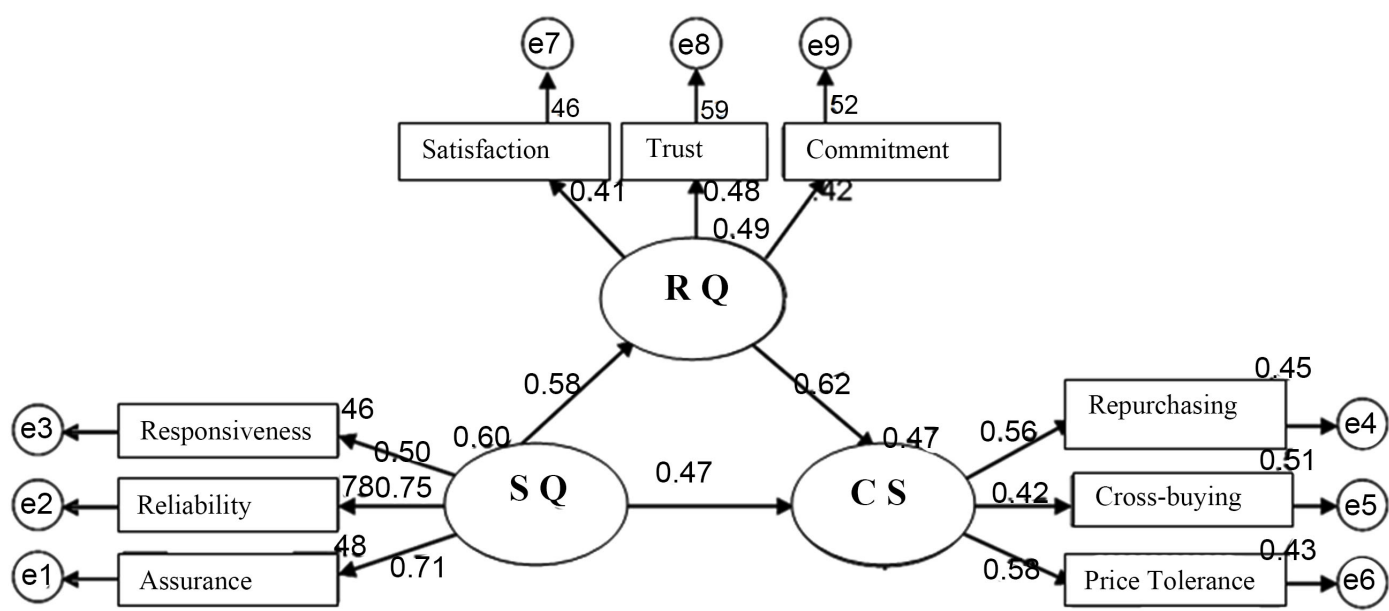

Figure 2. Structural Model of this Study.

we conducted effect decomposition. Inspecting the model of service quality and customer loyalty, we found that the total effect of service quality on customer loyalty is 0.569 , inspecting the comprehensive structural model we noted that the direct effect of service quality on customer loyalty was 0.469 ; service quality effect on relationship quality was 0.582 , relationship quality decomposed effect on customer loyalty was 0.624 , therefore, the mediating effect was $0.582 \times 0.624=$ 
0.363 , which suggests that relationship quality played a partially mediating role between service quality and customer loyalty, therefore, hypothesis $\mathrm{H} 4$ is supported.

\section{Discussion}

Customer loyalty, which generally refers to the strong commitment to repurchase a preferred product or service (Kim et al. 2018), is among the most discussed topics in business management and marketing literature. The interest of researchers about customer loyalty began in the year 2000 and still growing in the scientific research community (Moretta et al., 2019).

Service quality and relationship quality have been attracting a great deal of attention in the academia recently, nevertheless, previous studies have limitations in terms of industry background, imperfections and lack of research on the overall impact of these two constructs on customer loyalty, as well as scarcity of empirical models. After extensively reviewing related literature, we proposed a conceptual model depicting the interactions between service quality, relationship quality, and customer loyalty, as well as proposing the corresponding hypotheses. In this study, we investigated 75 eyewear foundries of Guangdong Province, questionnaires were distributed to 270 of their major customers, including eyewear brand owning firms and trading organizations. Based on the data obtained, we empirically examined the relationships between service quality, relationship quality, and customer loyalty.

Service management literature suggests that service quality impacts customer loyalty, which in turn affects firm performance. This literature argues that customer satisfaction is the outcome of a customer's perceived value of a transaction or relationship, where value means perceived service quality in comparison with price and costs of acquisition by customers, compared to potential value from transactions or relationships with competing suppliers (Meesala \& Paul, 2018; Zeithaml et al., 1990). Loyalty behaviours, including a lasting relationship, enhanced scale or scope of relationship, and word of mouth, result from customers' perceptions that the amount of value provided by one supplier is greater than that available from other vendors (Hallowell, 1996). Service quality positively impacts customer loyalty (Budianto, 2019).

The dominant force of the marketing activities of an organization is commonly understood in terms of development, maintenance, or enhancement of customers' loyalty toward its services and products (Dick and Basu, 1994). Constructing a very loyal customer base could not be achieved by adding on ideas copied from other firms, it should be an integral part of a firm's basic business strategy and customer loyalty should be the core issue around which the entire business system is built (Reichheld, 1993).

The results of this study suggest the inference of relationships between service quality, relationship quality and customer loyalty. The consistency of the findings with previous research (Meesala \& Paul, 2018) and among the several measures strengthens this conclusion. 
Firms should target and serve customers whose needs they can satisfy better than the competition in a profitable way. This type of customers are most likely to be loyal for the long run, they will buy multiple products and services, will recommend the firm to their family and friends, and might be a source of competitive advantage to the firm and its shareholders (Hallowell, 1996). Firms need to acknowledge that customer loyalty is attained through consistently delivering high value. Through grasping the economic impacts of customer retention on costs and revenues.

\section{Conclusion}

Service quality and relationship quality are key factors underlying customer loyalty. This is one of the first empirical studies that empirically examine the effects of four dimensions of service quality and three dimensions of relationship quality on retaining loyal customers, taking the viewpoint of social exchange theory into consideration. Based on the conceptual and empirical evidence, this research yielded some meaningful conclusions and implications.

\subsection{Theoretical Contributions}

This study intentionally made an effort to contribute to the growing body of theoretical and empirical knowledge on the relationships among service quality, relationship quality, and customer loyalty. Such research is called for by many scholars (Hallowell, 1996).

In order to explore the interactions between these three constructs, this paper established a comprehensive conceptual model that integrates these three variables together. This research can be perceived as expansion and integration of previous studies. In recent years, due to a flourishing service sector, many scholars have conducted studies on the meaning and impacts of service quality from a service industry point of view, manufacturing industry has attracted far less attention. However, the quality of service for today's manufacturing firms is crucial as well. If a firm has a better service capability, such as providing timely and precise services to meet customers' needs, as well as providing higher value-added services accompanying its products, then it will succeed in laying a more solid foundation for its future development. On the one hand, when customers have the same needs, they will continue to choose the same firm, or when the firm develops similar products or services, customer responses can be relatively easily obtained. On the other hand, due to the cooperation past experiences in which organizations have reduced possible uncertainties on the customers' side by providing timely and reliable products and/or services, these past experiences will build vivid impressions of the firm as a reliable and trustworthy partner, these interactive processes will lead to establish high quality relationships, which will help keeping loyal customers to stay loyal in the long run.

Based on our sample data, we investigated the mediating role of relationship quality between service quality and customer loyalty, further revealing the signi- 
ficance of relationship quality, including satisfaction, trust, and commitment, in maintaining customer loyalty. Our study not only empirically extended relationship quality dimensions, but also complemented previous studies that have focused only on certain dimensions of relationship quality that affect customer loyalty.

Our research can be seen as an expanding application of social exchange theory. Although scholars have not reached consensus on the dimensions that constitute relationship quality yet, many studies regard satisfaction, trust and commitment as significant factors that could lead to higher relationship quality, therefore, this paper uses these three dimensions to measure relationship quality and its impacts. Based on social exchange theory, mutual beneficial interactions between customers and businesses cannot be established in the short run, relying solely on products is also less likely to yield it, to meet changing, dynamic, diverse, and multi-level needs of customers, firms must focus on product quality, but at the same time they should establish business-customer trust and satisfaction through timely and accurately responding to customer needs, providing reliable services, and increasing value-added services. Establishing high quality relationships not only can reduce customers' uncertainty, but also can increase switching costs for customers, thereby setting exit barriers and make it difficult for them to end existing business relationships. Therefore, in this network of social relations, establishing a certain level of trust and commitment between customers and firms on the one hand has brought convenience to satisfying customers' needs, on the other hand, it also constitutes a constraint between the customer and the firm, such constraints would make customers more likely to become loyal.

\subsection{Managerial Implications}

The results of this study have significant implications for practitioners. Currently in China, manufacturing industry is witnessing a very intense competition, simply focusing on production has very little return. Therefore, producing services that goes along the production processes have become the main source of product differentiation and value-adding, as well as being a decisive factor of non price-competitiveness in the manufacturing industry. Frequent replacement of foundries by world-class brand managing organizations has demonstrated that customer loyalty management levels of hundreds of Chinese eyewear foundries have much room for improvement. The concept of leading through price and product seems slightly outdated nowadays. The pressures of a rising value Chinese currency and the rapidly increasing minimum wage requirements imposed by the government have made it particularly important for small-profit-margin manufacturing businesses to improve their service quality and relationship quality to grow and attain loyal customers.

Firstly, improving the quality of services, especially responsiveness, reliability, and assurance of services, as well as establishing and maintaining efficient customer service processes are important prerequisites to achieving customer loyal- 
ty. In terms of services responsiveness, firms should establish customer service management systems, such as the development of management processes, and building software to keep abreast of customers' needs and manage customers' complaints, while also training the staff to have better attitudes towards customer needs. Fast and convenient customer service can improve customer loyalty, therefore, in an era of rapid industry development, firms must keep up with the rapid pace of customers, timely support for customers will lead to establishing high quality customer relationships, thereby enhancing customer loyalty. In terms of reliability and assurance, firms should intensify training of customer service team to have relevant and required skills to be able to provide timely and effective services. At the same time firms need to establish a system for monitoring customer complaints and the proportion of how customer requirements are processed in a timely and satisfactory manner, continue to improve customer service efficiency and effectiveness, in order to achieve the best customer satisfaction results. Firms must continue improving customer service efficiency and effectiveness, in order to achieve the best customer satisfaction outcomes.

Secondly, firms need to establish high standards of customer relationship quality. Having the ability to improve the quality of services, upgrade firm's image, improve reaction speed, focus on customers' core concerns, continue to provide customers with reliable products and services, and to ensure customer needs, these are important issues for a firm to achieve and maintain good customer relations. Customer relations are difficult to be quantified, therefore it is better for organizations to establish assessment mechanisms and to develop relevant indicators, another option is to make use of customer relationship management software to improve the relationship quality with customers, as well as enhancing customer relations by quantifying or refinement and application of technical support to improve customer loyalty quality and. Firms should focus on developing relations with strategic partnerships and potential customers who play key roles in the development of the firm, as well as maintaining continuous improvement of products, services, and relations standards. Experiences from the developed world have shown that excellent firms attach great importance to enhancing relations with customers (suppliers), one example is Toyota Motor Corporation, which is one of the top players in manufacturing industry, it has developed a lean, zero inventory business plan, providing suppliers with free counseling and improvements, aiming at securing the reliability of their supply chain. This idea proved to be correct and advanced, $70 \%$ of Toyota's major materials suppliers have continued cooperating with Toyota for more than a decade. Therefore, building strong relationships with customers, providing satisfactory and reliable products and services, being committed to reach customers on time, all these are the keys to enhancing customer loyalty, as well as the necessary conditions for sustainable development of firms.

\subsection{Research Limitations and Future Directions}

In this study, questionnaire surveys were carried out in separate stages, and 
structural equation modeling was used to empirically examine the relationships between service quality, relationship quality, and customer loyalty. Measures were taken to ensure the rigor of the study to the greatest possible extent, however, this study has some limitations.

Firstly, the limitations of sectors and regions. Our study was limited to eyewear foundries in Guangdong Province, and since different industry sectors have different characteristics, and consumers in different regions may have different preferences, therefore, it might be difficult to take into account the external validity while ensuring the internal validity. Future research could be expanded to study different industries from different regions.

Secondly, variables and path selecting limitations. In this paper, relationship quality was chosen to be the mediating variable, it is possible that other variables may exist between service quality and customer loyalty, such as customer satisfaction; and there may be other impact paths between service quality and relationship quality. To handle these issues, follow-up studies can try examining different impact paths and conducting further in-depth research regarding interactions between service quality, relationship quality, and customer loyalty, thereby making further theory improvements to offer guidance to practitioners.

\section{Conflicts of Interest}

The author declares no conflicts of interest regarding the publication of this paper.

\section{References}

Anderson, E. W., \& Sullivan, M. W. (1993). The Antecedents and Consequences of Customer Satisfaction for Firms. Marketing Science, 12, 125-143. https://doi.org/10.1287/mksc.12.2.125

Athanasopoulou, P. (2009). Relationship Quality: A Critical Literature Review and Research Agenda. European Journal of Marketing, 43, 583-610. https://doi.org/10.1108/03090560910946945

Beneke, J., Mill, J., Naidoo, K., \& Wickham, B. (2015). The Impact of Willingness to Engage in Negative Electronic Word-of-Mouth on Brand Attitude: A Study of Airline Passengers in South Africa. Journal of Business and Retail Management Research, 9, 68-84.

Blau, P. (2017). Exchange and Power in Social Life. ¡Abingdon-on-Thames! Routledge. https://doi.org/10.4324/9780203792643

Budianto, A. (2019). Customer Loyalty: Quality of Service. Journal of Management Review, 3, 299-305. https://doi.org/10.25157/jmr.v3i1.1808

Caceres, C. R., \& Paparoidamis, N. G. (2007). Service Quality, Relationship Satisfaction, Trust, Commitment and Business-to-Business Loyalty. European Journal of Marketing, 41, 836-867. https://doi.org/10.1108/03090560710752429

Carrillat, F. A., Jaramillo, F., \& Mulki, J. P. (2009). Examining the Impact of Service Quality: A Meta-Analysis of Empirical Evidence. Journal of Marketing Theory and Practice, 17, 95-110. https://doi.org/10.2753/MTP1069-6679170201

Caruana, A. (2002). Service Loyalty: The Effects of Service Quality and the Mediating 
Role of Customer Satisfaction. European Journal of Marketing, 36, 811-828. https://doi.org/10.1108/03090560210430818

Chenet, P., Dagger, T. S., \& O’Sullivan, D. (2010). Service Quality, Trust, Commitment and Service Differentiation in Business Relationships. Journal of Services Marketing, 24, 336-346. https://doi.org/10.1108/08876041011060440

Cronin, J. J., \& Taylor, S. A. (1992). Measuring Service Quality: A Reexamination and Extension. Journal of Marketing, 56, 55-68. https://doi.org/10.1177/002224299205600304

Crosby, L. A., Evans, K. R., \& Cowles, D. (1990). Relationship Quality in Services Selling: An Interpersonal Influence Perspective. Journal of Marketing, 54, 68-81. https://doi.org/10.1177/002224299005400306

Fornell, C. (1992). A National Customer Satisfaction Barometer: The Swedish Experience. Journal of Marketing, 56, 6-21. https://doi.org/10.1177/002224299205600103

Grönroos, C. (1984). A Service Quality Model and Its Marketing Implications. European Journal of Marketing, 18, 36-44. https://doi.org/10.1108/EUM0000000004784

Grönroos, C. (2002). Service Management and Marketing. Hoboken, NJ: John Wiley \& Sons.

Hajli, N., Shanmugam, M., Papagiannidis, S., Zahay, D., \& Richard, M. O. (2017). Branding Co-Creation with Members of Online Brand Communities. Journal of Business Research, 70, 136-144. https://doi.org/10.1016/j.jbusres.2016.08.026

Hallowell, R. (1996). The Relationships of Customer Satisfaction, Customer, Loyalty, and Profitability: An Empirical Study. International Journal of Service Industry Management, 7, 27-42. https://doi.org/10.1108/09564239610129931

Hazra, S. G., \& Srivastava, K. B. (2009). Impact of Service Quality on Customer Loyalty, Commitment and Trust in the Indian Banking Sector. IUP Journal of Marketing Management, 8, 74-95.

Hewett, K., Money, R. B., \& Sharma, S. (2002). An Exploration of the Moderating Role of Buyer Corporate Culture in Industrial Buyer-Seller Relationships. Journal of the Academy of Marketing Science, 30, 229-239.

https://doi.org/10.1177/0092070302303004

Hu, H. H., Kandampully, J., \& Juwaheer, T. D. (2009). Relationships and Impacts of Service Quality, Perceived Value, Customer Satisfaction, and Image: An Empirical Study. The Service Industries Journal, 29, 111-125. https://doi.org/10.1080/02642060802292932

Huntley, J. K. (2006). Conceptualization and Measurement of Relationship Quality: Linking Relationship Quality to Actual Sales and Recommendation Intention. Industrial Marketing Management, 35, 703-714. https://doi.org/10.1016/j.indmarman.2005.05.011

Hussain, R., Al Nasser, A., \& Hussain, Y. K. (2015). Service Quality and Customer Satisfaction of a UAE-Based Airline: An Empirical Investigation. Journal of Air Transport Management, 42, 167-175. https://doi.org/10.1016/j.jairtraman.2014.10.001

Iqbal, M. S., Hassan, M. U., \& Habibah, U. (2018). Impact of Self-Service Technology (SST) Service Quality on Customer Loyalty and Behavioral Intention: The Mediating Role of Customer Satisfaction. Cogent Business \& Management, 5, 799-813. https://doi.org/10.1080/23311975.2018.1423770

Juga, J., Juntunen, J., \& Grant, D. B. (2010). Service Quality and Its Relation to Satisfaction and Loyalty in Logistics Outsourcing Relationships. Managing Service Quality: An International Journal, 20, 496-510. https://doi.org/10.1108/09604521011092857 
Kalepu, R. N. P. (2014). Service Quality in Healthcare Sector: An Exploratory Study on Hospitals. IUP Journal of Marketing Management, 13, 7-28.

Keaveney, S. M. (1995). Customer Switching Behavior in Service Industries: An Exploratory Study. Journal of Marketing, 59, 71-82. https://doi.org/10.1177/002224299505900206

Kim, M. K., Park, M. C., Park, J. H., Kim, J., \& Kim, E. (2018). The Role of Multidimensional Switching Barriers on the Cognitive and Affective Satisfaction-Loyalty Link in Mobile Communication Services: Coupling in Moderating Effects. Computers in $\mathrm{Hu}$ man Behavior, 87, 212-223. https://doi.org/10.1016/j.chb.2018.05.024

Kotler, P. R. (1997). Marketing Management: Analysis, Planning, Implementation, and Control. Upper Saddle River, NJ: Prentice Hall.

Lee, C. K., Lee, Y. C., Chuang, Y. S., \& Wu, W. L. (2014). The Effect of Electronic Word-of-Mouth, Customer Expectations, and Emotions on Intention to Take Low Cost Airlines. Advanced Approaches to Intelligent Information and Database Systems, Studies in Computational Intelligence, 55, 69-75.

https://doi.org/10.1007/978-3-319-05503-9 7

Lerrthaitrakul, W., \& Panjakajornsak, V. (2014). The Impact of Electronic Word-of-Mouth Factors on Consumers' Buying Decision-Making Process in the Low Cost Carriers: A Conceptual Framework. International Journal of Trade, Economics and Finance, 5, 142-146. https://doi.org/10.7763/IJTEF.2014.V5.357

Liu, C. T., Guo, Y. M., \& Lee, C. H. (2011). The Effects of Relationship Quality and Switching Barriers on Customer Loyalty. International Journal of Information Management, 31, 71-79. https://doi.org/10.1016/j.ijinfomgt.2010.05.008

Meesala, A., \& Paul, J. (2018). Service Quality, Consumer Satisfaction and Loyalty in Hospitals: Thinking for the Future. Journal of Retailing and Consumer Services, 40, 261-269. https://doi.org/10.1016/j.jretconser.2016.10.011

Merkert, R., \& Pearson, J. (2015). A Non-Parametric Efficiency Measure Incorporating Perceived Airline Service Levels and Profitability. Journal of Transport Economics and Policy, 49, 261-275.

Moretta, T. A., Cavacece, Y., Russo, G., \& Granata, G. (2019). A Systematic Mapping Study on Customer Loyalty and Brand Management. Administrative Sciences, 9, 8-29. https://doi.org/10.3390/admsci9010008

Nguyen, H., Nguyen, H., Nguyen, N., \& Phan, A. (2018). Determinants of Customer Satisfaction and Loyalty in Vietnamese Life-Insurance Setting. Sustainability, 10, 1151-1168. https://doi.org/10.3390/su10041151

Nguyen, N., Leclerc, A., \& LeBlanc, G. (2013). The Mediating Role of Customer Trust on Customer Loyalty. Journal of Service Science and Management, 6, 96-109. https://doi.org/10.4236/jssm.2013.61010

Ou, W. M., Shih, C. M., Chen, C. Y., \& Wang, K. C. (2011). Relationships among Customer Loyalty Programs, Service Quality, Relationship Quality and Loyalty: An Empirical Study. Chinese Management Studies, 5, 194-206. https://doi.org/10.1108/17506141111142825

Pan, Y., Sheng, S., \& Xie, F. T. (2012). Antecedents of Customer Loyalty: An Empirical Synthesis and Reexamination. Journal of Retailing and Consumer Services, 19, 150-158. https://doi.org/10.1016/j.jretconser.2011.11.004

Parasuraman, A., Berry, L. L., \& Zeithaml, V. A. (1991). Refinement and Reassessment of the SERVQUAL Scale. Journal of Retailing, 67, 420-450.

Parasuraman, A., Zeithaml, V. A., \& Berry, L. L. (1985a). Problems and Strategies in Ser- 
vices Marketing. Journal of Marketing, 49, 33-46. https://doi.org/10.1177/002224298504900203

Parasuraman, A., Zeithaml, V. A., \& Berry, L. L. (1985b). A Conceptual Model of Service Quality and Its Implications for Future Research. Journal of Marketing, 49, 41-50. https://doi.org/10.1177/002224298504900403

Podsakoff, P. M., MacKenzie, S. B., Lee, J. Y., \& Podsakoff, N. P. (2003). Common Method Biases in Behavioral Research: A Critical Review of the Literature and Recommended Remedies. Journal of Applied Psychology, 88, 879-903. https://doi.org/10.1037/0021-9010.88.5.879

Punel, A., Al Hajj Hassan, L., \& Ermagun, A. (2019). Variations in Airline Passenger Expectation of Service Quality across the Globe. Tourism Management, 75, 491-508. https://doi.org/10.1016/j.tourman.2019.06.004

Reichheld, F. F. (1993). Loyalty-Based Management. Harvard Business Review, 71, 64-73.

Shi, S., Mu, R., Lin, L., Chen, Y., Kou, G., \& Chen, X. J. (2018). The Impact of Perceived Online Service Quality on Swift Guanxi: Implications for Customer Repurchase Intention. Internet Research, 28, 432-455. https://doi.org/10.1108/IntR-12-2016-0389

Singh, J., \& Sirdeshmukh, D. (2000). Agency and Trust Mechanisms in Consumer Satisfaction and Loyalty Judgments. Journal of the Academy of Marketing Science, 28, 150-167. https://doi.org/10.1177/0092070300281014

Sitorus, T., \& Yustisia, M. (2018). The Influence of Service Quality and Customer Trust toward Customer Loyalty: The Role of Customer Satisfaction. International Journal for Quality Research, 12, 639-654.

Uncles, M. D., Dowling, G. R., \& Hammond, K. (2003). Customer Loyalty and Customer Loyalty Programs. Journal of Consumer Marketing, 20, 294-316. https://doi.org/10.1108/07363760310483676

Walsh, G., Evanschitzky, H., \& Wunderlich, M. (2008). Identification and Analysis of Moderator Variables: Investigating the Customer Satisfaction-Loyalty Link. European Journal of Marketing, 42, 977-1004. https://doi.org/10.1108/03090560810891109

Zeithaml, V. A., Berry, L. L., \& Parasuraman, A. (1996). The Behavioral Consequences of Service Quality. Journal of Marketing, 60, 31-46. https://doi.org/10.2307/1251929

Zeithaml, V., Parasuraman, A., \& Berry, L. L. (1990). Delivering Quality Service. New York: The Free Press. 